\title{
The Current Status of Stem Cell Regeneration in Intra Oral Applications-A Systematic Review
}

\author{
Abbasi Kanwal'1, Jovita D’souza ${ }^{2 *}$, Lovely Muthiah ${ }^{3}$, S. Srividya ${ }^{4}$ \\ ${ }^{1}$ Department of Biochemistry, Ras Al khaimah College of Dental Sciences, RAK, UAE \\ ${ }^{2}$ Department of Periodontics, Ras Al Khaimah College of Dental Sciences, RAK, UAE \\ ${ }^{3}$ Department of Prosthodontics, Ras Al khaimah College of Dental Sciences, RAK, UAE \\ ${ }^{4}$ Department of Prosthodontics, AECS Maruti College of Dental Sciences, Banglore, India \\ Email: *dr.jovita@gmail.com
}

How to cite this paper: Kanwal, A., D'souza, J., Muthiah, L. and Srividya, S. (2017) The Current Status of Stem Cell Regeneration in Intra Oral ApplicationsA Systematic Review. Open Journal of Stomatology, 7, 197-224.

https://doi.org/10.4236/ojst.2017.74015

Received: February 7, 2017

Accepted: April 14, 2017

Published: April 17, 2017

Copyright $\odot 2017$ by authors and Scientific Research Publishing Inc. This work is licensed under the Creative Commons Attribution International License (CC BY 4.0).

http://creativecommons.org/licenses/by/4.0/

\begin{abstract}
Aim: 1) To review the literature of various applications of stem cell regeneration in dentistry from 2010 to 2016. 2) To review these studies and to summarize the current status of stem cell regeneration in intra oral applications. 3) To present the available successful data with regard to stem cell regeneration in dentistry and to highlight the future trends. Materials and Methods: Search Protocol: A systematic search was made in the PubMed database with the key words gingiva, papillary reconstruction, periodontal ligament, dental pulp, salivary gland, enamel re-mineralization, dentin, cementum, bone, whole tooth, cleft palate, regeneration and stem cells. All articles from 2010 to 2016, relevant to the topic were included. After the search a total of 1826 articles were obtained which were screened and categorized by three independent reviewers as review papers, in vitro, animal and human studies, pertaining to stem cell regeneration in intra oral applications. On the basis of the extracted data and outcome measures, conclusions were drawn. Results: Maximum number of animal studies has been done to regenerate periodontal tissues, bone, dentin and pulp tissues. Few human studies have been done till date. Although clinically, researchers have been able to regenerate periodontal-like tissue, bone and pulp-like tissue, they still haven't been able to regenerate tissues that completely resemble tissues in their natural form. Conclusion: The future of stem cell therapy in dental applications looks promising. The predictability and efficacy of outcomes, as well as safety concerns of stem cell therapy is yet to be fully established. Ongoing research and development of newer scaffolds, understanding various signaling molecules and their cues, understanding gene expression and proteomics of stem cells are the future directions that will take us a step forward to achieving successful regeneration.
\end{abstract}

\section{Keywords}

Stem Cells, Regeneration, Dental Tissues 


\section{Introduction}

Stem cells are defined as clonogenic cells capable of both self-renewal and multi-lineage differentiation [1]. The term "stem cell" first appeared in 1868 in the works of German biologist Haeckel [2], but was proposed for scientific use in 1908 [3]. In the 19th century, Goujon observed that transplantation of bone marrow to heterotopic anatomical sites resulted in de novo generation of ectopic bone and marrow [4]. Later, the work of Tavassoli and Crosby clearly established proof of an inherent osteogenic potential associated with the bone Marow [5]. Friedenstein et al. isolated Mesenchymal stem cells (MSC) from bone marrow in 1974 [6]. But, the major breakthrough in dental history was achieved by Gronthos et al. [7] in the year 2000.

Stem cells can be broadly classified into embryonic stem cells, adult stem cells and induced pluripotent stem cells (iPS).

Embryonic stem cells are undifferentiated pluripotent cells that are obtained from the inner cell mass of the blastocyst having the ability to form any adult cell [8].

Adult stem cells are also called somatic stem cells or postnatal stem cells, and they are found in many tissues and organs. These cells undergo self-renewal and differentiation to maintain healthy tissues and repair injured tissues [9]. Recent stem cell studies in the dental field have identified many adult stem cell sources in the oral and maxillofacial region. These cells are believed to reside in a specific area of each tissue, i.e., a "stem cell niche". Many types of adult stem cells reside in several mesenchymal tissues, and these cells are collectively referred to as mesenchymal stem cells or multipotent mesenchymal stromal cells (MSCs). Mesenchymal stem cells can be bone marrow derived, dental tissue-derived cells, umbilical cord derived and fat tissue derived cells that are capable of self-renewing by dividing and differentiating into multiple tissues such as bone, cartilage, muscle, fat cells, and connective tissue [10] [11]. Bone marrow-derived MSCs (BMSCs) are multipotent progenitor cells which can be harvested from sternum or iliac crest and [12] and Orofaical (maxilla and mandible) bone marrows [13]. Dental tissue-derived mesenchymal stem cells have being documented to be good, due to their easy accessibility, immunosuppressive properties, high proliferation, and the capacity to differentiate into odontoblasts, cementoblasts, osteoblasts, and other cells to be found in dental tissues [14] [15].

There are five different types of dental tissue derived stem cells which are Dental pulp stem Cells (DPSCs), Periodontal ligament stem cells (PDLSCs), Stem cells from exfoliated deciduous teeth (SHED), Stem cells from apical papilla (SCAP) and Dental follicle progenitor cells (DFPCs).

Dental pulp stem Cells (DPSCs) can differentiate into different kinds of cells and tissues [16] [17] especially bone-like tissue and their multipotency has been compared to those of bone marrow stem cells (BMSCs). It has been demonstrated that proliferation, availability, and cell number of DPSCs are greater than BMSCs [18]. DPSC have also been used to regenerate nerves [19], cornea [20], bladder and renal tissues [21] [22], skeletal muscles [23], lung tissue [24] and has 
demonstrated good angiogenic [25] and neurogenic potential.

PDLSCs (Periodontal Ligament stem cells) are capable of regenerating bone, cementum, periodontal ligament-like structures and facilitates periodontal regeneration [26].

SHEDs (Stem cells from human exfoliated deciduous teeth) also have periodontal regeneration, dentin pulp-like complex and bone regenerative capacity [27] [28].

SCAPs (stem cells from apical papilla) demonstrated positive results in formation of dentin pulp-like complex and were able to form a root-like structure when seeded onto hydroxyapatite-based scaffolds and implanted in pig jaws [29] [30] [31].

DFPCs (Dental follicle precursor cells) are observed to have potential for dentin regeneration, matrix formation in skull, formation of root like tissues with a pulp-dentin complex and a periodontal ligament connecting a cementum-like layer to host alveolar bone. These cells are isolated from follicles of human impacted third molars [32]. DPSCs, SHEDs and PDLSCs have all demonstrated bone regenerating capacity in in-vitro and in-vivo studies.

Gingiva-derived mesenchymal stem cells (G-MSC) have also been used to regenerate bone. In a comparative study of different mesenchymal stem cells, the gingiva and dental pulp stem cells proved to be putative cell sources for hard tissue regeneration [33].

In 2006, Dr. Shinya Yamanaka discovered that normal mouse adult skin fibroblasts can be reprogrammed to an embryonic state by introducing four genetic factors and the resulting cells were termed iPS cells [34]. iPS cells have been generated from various oral mesenchymal cells for dental applications.

There are numerous types of tissues that are being attempted to be regenerated with stem cells. We will limit the scope of this article to the intraoral applications of the various types of stem cells and systematically review the current status of stem cell regeneration in various intra oral hard and soft tissues.

\section{Materials and Methods}

A systematic search was made in the PubMed database with the key words gingiva, papillary reconstruction, periodontal ligament, dental pulp, salivary glands, Enamel re-mineralisation, dentin, cementum, bone, whole tooth, cleft palate, regeneration and stem cells. Key words pertaining to all the intraoral soft and hard tissues were used in combination with stem cells and regeneration in order to obtain all the relevant articles pertaining to various tissues.

All articles from 2010 to 2016, relevant to the topic were included. After the search a total of 1826 articles were obtained which were screened and categorized by three independent reviewers as review papers, in vitro and in vivo (animal and human) studies, pertaining to stem cell regeneration in intra oral applications.

Inclusion criteria: Animal and human studies using stem cells for intraoral hard and soft tissue regeneration were included in the review. Articles in English 
language were only included.

183 articles were included but only the most relevant articles were cited in the review.

Exclusion criteria: Narrative review articles, commentaries, opinions were excluded from the study.

Figure 1 illustrates the screening process, selection and exclusion of articles after a PUBMED search.

\section{Results}

A total of 1826 articles were obtained after the PUBMED database search. The distribution of the articles according to intraoral hard and soft tissue regeneration based on the type of study after the initial search is depicted in Table 1. Out

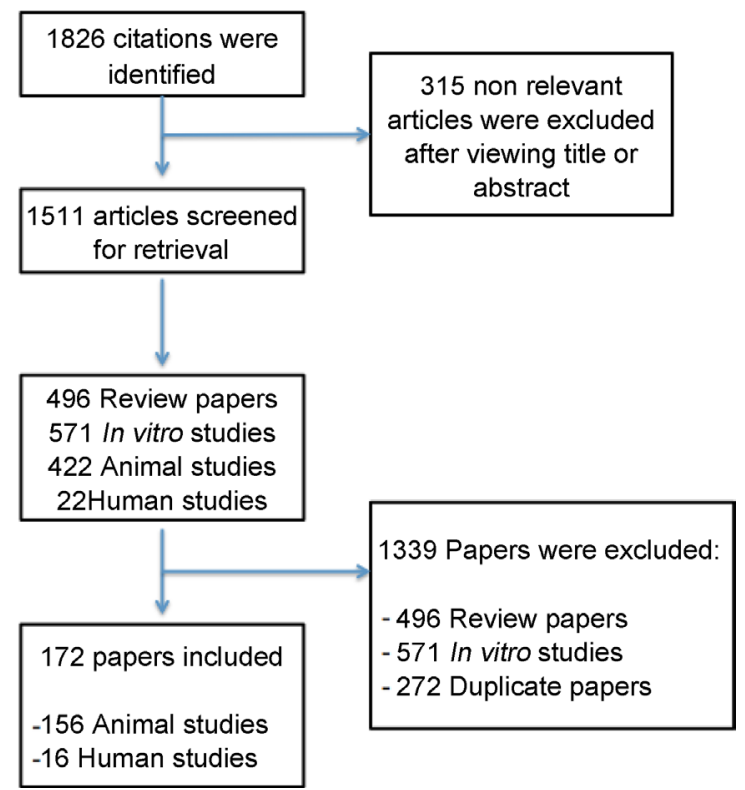

Figure 1. Flow diagram depicting article-screening process.

Table 1. Distribution of the articles pertaining to intraoral hard and soft tissue regeneration with stem cells according to the type of study after initial search.

\begin{tabular}{cccccc}
\hline $\begin{array}{c}\text { Tissue } \\
\text { regenerated }\end{array}$ & $\begin{array}{c}\text { Total articles } \\
(\mathbf{n}=\mathbf{1 8 2 6})\end{array}$ & $\begin{array}{c}\text { Review papers } \\
(\mathbf{n}=\mathbf{4 9 6})\end{array}$ & $\begin{array}{c}\text { In vitro studies } \\
(\mathbf{n}=\mathbf{5 7 1})\end{array}$ & $\begin{array}{c}\text { Animal studies } \\
(\mathbf{n}=\mathbf{4 2 2})\end{array}$ & $\begin{array}{c}\text { Humans studies } \\
(\mathbf{n}=\mathbf{2 2})\end{array}$ \\
\hline Gingiva & 60 & 18 & 23 & 13 & 2 \\
PDL & 317 & 73 & 151 & 84 & 4 \\
Pulp & 474 & 127 & 194 & 87 & 6 \\
Salivary & 56 & 28 & 9 & 15 & 1 \\
Bone & 500 & 135 & 80 & 81 & 7 \\
Dentin & 222 & 47 & 83 & 63 & 1 \\
Enamel & 56 & 25 & 14 & 11 & 0 \\
Cleft palate & 16 & 5 & 1 & 6 & 0 \\
Whole tooth & 22 & 15 & 1 & 6 & 0 \\
Cementum & 103 & 23 & 15 & 56 & 1 \\
\hline
\end{tabular}


of the total number of articles, $27 \%$ were review articles, $32 \%$ were In vitro studies, $23 \%$ were animal studies and only $1 \%$ were human studies (Figure 2). Articles that were not in English language and overlapping articles that appeared due to similar key words were excluded and only animal and human studies pertaining to the topic were further analyzed. A detailed distribution of the number of studies done in animals and humans to regenerate various intraoral soft and hard tissues has been presented in Table 2. A total of 156 animal studies and 16 human studies were included in this review.

After comparative evaluation of all type of articles between 2010 to 2016 pertaining to stem cell therapy application in intraoral hard and soft tissue application it was observed that till date maximum number of animal studies have been done to regenerate Periodontal tissues, Bone, Dentin and pulp tissues. Very few human studies have been done till date (Figure 3 ).

\section{Discussion}

The use of stem cells for tissue engineering has great potential to solve clinical and surgical problems related to tissue loss and organ functional failures. For the ease of data analysis, we classified the intraoral applications of stem cell therapy according to soft and hard tissue regeneration.

\section{Soft Tissue Regeneration}

\subsection{Gingiva}

\subsubsection{Animal Studies}

\section{Mucogingival defects}

Mucogingival defects have been treated successfully in animal models with amniotic membranes used as 3D scaffolds and bone marrow stem cells. The defects were completely closed on the seventh day, colour matching was good and scaffold was well tolerated by the gingival tissues [35]. Amniotic membranes boost angiogenesis and increase reparative regeneration of damaged tissues.

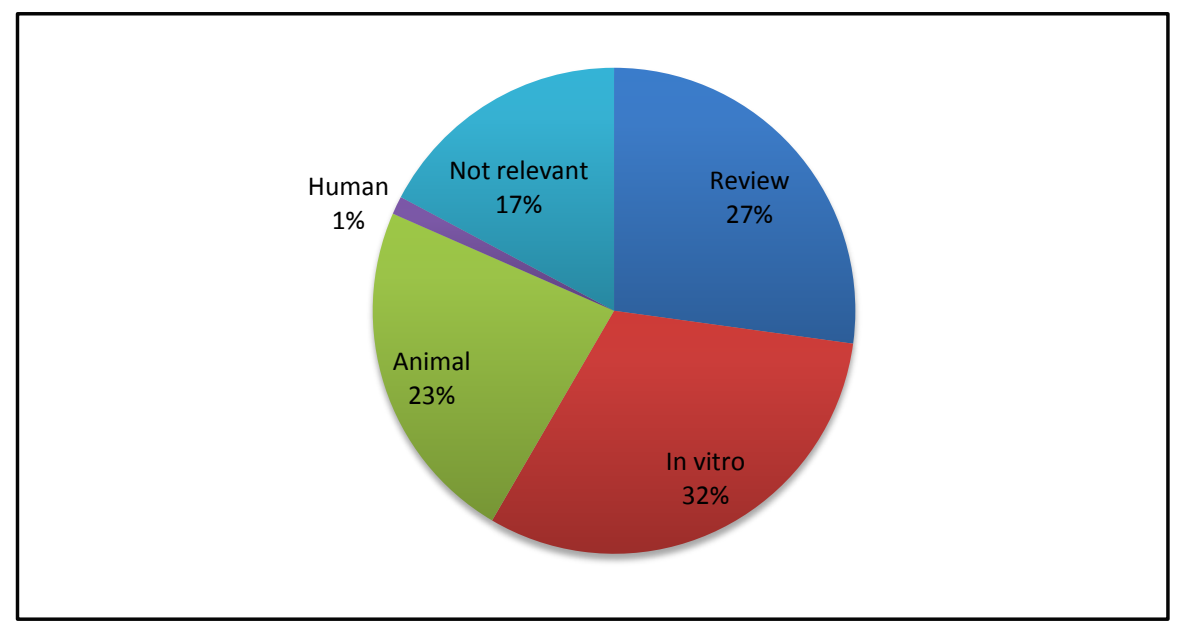

Figure 2. Percentage of the type of studies in intraoral hard and soft tissue regeneration with stem cells. 
Table 2. Number of animal and human studies done to regenerate various intraoral hard and soft tissues.

\begin{tabular}{|c|c|c|c|c|}
\hline & \multicolumn{2}{|l|}{ Number of Animal studies $(n=156)$} & \multicolumn{2}{|l|}{ Number of Human studies $(n=16)$} \\
\hline & Mucogingival defects & 1 & Root coverage & 2 \\
\hline \multirow[t]{3}{*}{ Gingiva } & Oral mucositis & 1 & Papillary reconstruction & 1 \\
\hline & Peri-implant mucosa & 1 & & \\
\hline & Pulp regeneration & 10 & Immature teeth & 1 \\
\hline \multirow[t]{3}{*}{ Dental Pulp } & Pulp-like tissue & 7 & Pulp revascularisation & 1 \\
\hline & Dentin/pulp complex & 5 & & \\
\hline & Dentin & 6 & & \\
\hline \multirow{5}{*}{ Dentin } & Dentin-like tissue & 4 & & \\
\hline & Odontogenic differentiation & 14 & & \\
\hline & Periodontal regeneration & 25 & Intrabony defects & 4 \\
\hline & Furcation defects & 4 & & \\
\hline & Periodontium like structure & 2 & & \\
\hline \multirow{8}{*}{$\begin{array}{l}\text { Periodontal } \\
\text { complex }\end{array}$} & Cementum/PDL complex & 4 & & \\
\hline & Cementum/cementum like & 5 & & \\
\hline & Cementum and bone & 1 & & \\
\hline & Periodntal defect model & 8 & & \\
\hline & Furcation perforation defect & 1 & & \\
\hline & Craniofacial/alveolar bone regeneration & 8 & Alveolar bone regeneration & 2 \\
\hline & Mandibular bone defect & 2 & Mandible defects & 1 \\
\hline & Bone/bone-like tissue & 13 & Craniofacial bone regeneration & 2 \\
\hline \multirow[t]{4}{*}{ Bone } & Maxillary alveolar defects (Cleft palate) & 4 & Alveolar cleft defects & 1 \\
\hline & Osteonecrosis & 1 & & \\
\hline & Peri-implant bone defect & 2 & & \\
\hline & Osseointegration of implants & 3 & & \\
\hline \multirow{3}{*}{ Enamel } & Enamel & 4 & & \\
\hline & Enamel + Dentin & 1 & & \\
\hline & Whole tooth & 2 & & \\
\hline \multirow[t]{3}{*}{ Whole tooth } & Bio-root & 1 & & \\
\hline & Tooth-like structure & 1 & & \\
\hline & Salivary gland regeneration & 6 & Sjogrens syndrome & 1 \\
\hline \multirow{3}{*}{ Salivary gland } & Radiation induced hyposalivation & 3 & & \\
\hline & Radiation induced xerostomia & 1 & & \\
\hline & Radiation damaged gland & 5 & & \\
\hline
\end{tabular}

\section{Mucositis}

Spheroid GMSCs are capable of enhanced multipotency and augmented secretion of several chemokines and cytokines relevant to cell migration, survival, and angiogenesis. Using an in vivo murine model of chemotherapy-induced oral mucositis, Moshaverinia et al. demonstrated that spheroid-derived GMSCs 


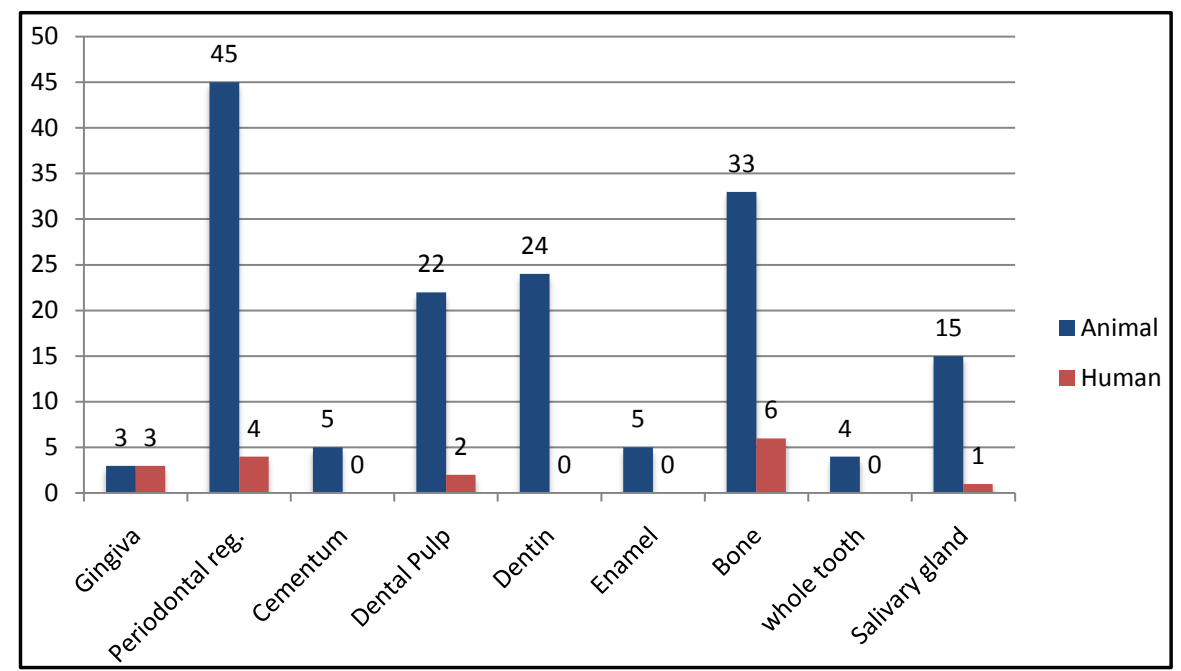

Figure 3. Comparison of the number of animal and human studies done to regenerate various intraoral hard and soft tissues.

promoted the regeneration of disrupted epithelial lining of the mucositic tongues, therefore, suggesting that 3D spheroid culture allows early stemness preservation and potentially precondition GMSCs for enhanced mitigation of oral mucositis [36].

\section{Peri-implant mucosa}

MSC transplantation accelerated the formation of the peri-implant epithelium-mediated mucosa around the implants at an early stage after implantation, hence reinforcing the epithelial seal around the dental implants [37].

\subsubsection{Human Studies}

\section{Root coverage procedures}

Predictable root coverage is possible for single-tooth and multiple-tooth recession defects, with subepithelial connective tissue graft (SCTG) procedures [38]. However, autogenous graft tissue procurement increases patient morbidity and duration of surgery. To avoid these complications stem cells in combination with membranes have been used clinically in the treatment of multiple gingival recession defects. Zanwar et al. compared the clinical efficacy between stem cells in combination with PLA/PGA membranes and subepithelial connective tissue graft (SCTG) in the treatment of multiple gingival recession defects and found that stem cells in combination with bioresorbable PLA/PGA membrane was effective for root coverage and resulted in a significant reduction in gingival recession and greater gain in CAL than SCTG [39]. Recently, various researchers have used resorbable amniotic membranes for root coverage procedures with successful outcomes [40]. Amniotic membranes not only maintain the structural and anatomical configuration of regenerated tissues, but also enhance gingival wound healing by providing a rich source of stem cells.

\section{Papilla reconstruction}

Currently, the available techniques to treat black triangles are to either augment the papilla itself or graft autogenous tissue surgically. However, these 
available techniques haven't been able to demonstrate predictable results. Yamada et al. in 2015 investigated the potential of a tissue-engineered method for soft tissue augmentation with mesenchymal stem cells (MSC), platelet-rich plasma (PRP) and Hyaluronic acid (HA) as the scaffold and achieved predictable results with aesthetic improvements in the black triangle. This technique could emerge as a novel option for periodontal regenerative therapy in the near future [41].

\subsection{Periodontal Complex}

Periodontal disease is one of the most common conditions affecting humans, and the prevalence of advanced periodontitis in adults is about $15 \%$ [42]. According to the American Academy of Periodontology in 2005 [43], the formation of new bone and cementum with supportive periodontal ligament is the ultimate objective that current periodontal-regenerative therapies are incapable of fulfilling. Most of the current regenerative procedures, used either alone or in combination, have limitations in attaining complete regeneration, especially in deep periodontal defects [44]. Stem cell therapy has shown some promising results to regenerate the periodontal apparatus.

\subsubsection{Animal Studies}

A total of 43 studies have been done in animals to regenerate periodontal tissues using different types of stem cells. 38 out of the 43 included studies demonstrated a statistically significant improvement in periodontal tissue regeneration.

\section{Periodontal regeneration}

Out of the 38 successful studies, 25 studies showed statistically significant improvements in periodontal regeneration.

Various types of stem cells have been used to regenerate the periodontal complex. Periodontal ligament stem cells and Bone marrow derived stem cells have been used successfully in most of the studies to regenerate the periodontium [45] [46] [47].

According to a systematic review, PDL-derived cells showed a favorable effect on new PDL formation, although there was no statistically significant difference between PDL-derived or Bone marrow derived stem cells [48]. Other cell types like DPSC [49], GMSC [50], DFAT [51], SHED [52] have also been able to successfully regenerate periodontal tissue.

2 studies demonstrated regeneration of periodontium-like tissue [53] [54]. Wang et al. isolated human PDL stem cells (PDLSCs) and jaw-bone mesenchymal stem cells (JBMSCs) and then induced them to form cell sheets. Platelet-rich fibrin (PRF) derived from human venous blood was then fabricated into bioabsorbable fibrin scaffolds containing various growth factors. Eight weeks after implantation, the PDLSC sheets tended to develop into PDL-like tissues, while the JBMSC sheets tended to produce predominantly bone-like tissues [54].

The enhancement of PDL derived cells in PDL regeneration is probably caused by the fact that PDL-derived cells contain several subpopulations of cells, 
including osteoblasts, fibroblasts, and cementoblasts, and the combined subpopulations of cells which can simultaneously synthesize both hard and soft periodontal tissues [55].

\section{Furcation defects}

A total of 4 studies have been done to treat furcation defects with stem cells. 2 studies showed promising results. They were able to improve periodontal regeneration in class II furcation defects and treated class III furcation defects with PDLSC and GTR [56]. Another study compared Autogeous cortical bone (ACB), $\mathrm{ACB} / \mathrm{PRP}$ and MSC/PRP. Complete filling of class II furcation defects with cementum, alveolar bone and PDL were obtained in 8 weeks, but the efficacy of none of the groups was higher than the other [57].

\section{Periodontal defect model}

8 studies have successfully been able to regenerate bone and periodontal structures in a critical size periodontal defect model. BMSC were used in 3 studies [58] [59], one of which was a one walled intra bony defect [60], PDLSC in 2 studies [61] [62], DPSC in 1 study [49] and adipose derived stem cell in one study [63] successfully. PDLSC were also used to treat periodontal fenestration defects and was able to form bone, PDL and cementum successfully [64].

\subsubsection{Human Studies}

In a pilot study, Feng et al. examined the feasibility and safety of reconstructing periodontal intrabony defects with autologous periodontal ligament progenitor (PDLP) implantation in three patients. All treated patients showed no adverse effects during the entire course of follow up. They also found that PDLPs were analogous to PDLSCs in terms of high proliferation, expression of mesenchymal surface molecules, multipotent differentiation, and in vivo tissue regain. However, PDLPs failed to express scleraxis, a marker of tendon, as seen in PDLSCs [65].

In a recent randomized clinical trial, Chen et al. assessed the safety and feasibility of using autologous periodontal ligament stem cells (PDLSCs) as an adjuvant to grafting materials in guided tissue regeneration (GTR) to treat periodontal intrabony defects. Each group showed a significant increase in the alveolar bone height over time. The efficacy of cell-based periodontal therapy requires further validation by multicenter, randomized controlled clinical studies with an increased sample size [66].

Dhote et al. performed a randomized controlled clinical trial to evaluate the effectiveness of mesenchymal stem cells cultured on beta tricalcium phosphate $(\beta$-TCP) in combination with rh-PDGF-BB in treatment of intrabony defect in humans and concluded added benefit in terms of CAL gains, PPD reductions greater radiographic defect fill and improvement in Linear bone growth (LBG) compared to the OFD alone [67].

Shunsuke et al. [68] evaluated the safety and efficacy of autologous mesenchymal stem cells (MSCs) with a biodegradable three-dimensional (3D) woven-fabric composite scaffold and platelet-rich plasma (PRP) in ten patients with intrabony defects. The trial suggested that MSCs-PRP/3D scaffold constituted a 
novel safe and effective regenerative treatment option for periodontitis.

The predictability and efficacy of outcomes, as well as safety concerns and the cost-to-benefit ratio of various treatment options are key factors to be considered for any new emerging technology. At this time, there is insufficient evidence on emerging periodontal regenerative technologies to warrant definitive clinical recommendations [69].

\subsection{Dental Pulp}

For treating pulpal pathological conditions, pulpal regeneration through transplanted stem/progenitor cells might be an alternative to conventional root canal treatment. A number of animal studies demonstrate beneficial effects of stem/progenitor cell transplantation for pulp-dentin complex regeneration.

\subsubsection{Animal Studies}

Out of a total of 22 animal studies, 15 studies demonstrated efficacy of DPSC in formation of vascularized pulp [70] [71] [72], pulp-like tissue [73] [74] or formation of pulp-dentin like complex [75] [76] in the root canal space and 1 study was able to form pulp tissue with BMSC [77].

Ishikazi et al. in their study demonstrated that pulp stem cells have higher angiogenic, neurogenic and regenerative potential and may therefore be superior to bone marrow and adipose stem cells for cell therapy [78].

DPSCs have rapid proliferation, multiple differentiation capacity, and development potential. Wang et al. transplanted these cells into the pulpless root canal with Gelfoam as the scaffold and they were capable of generating pulp-like tissues containing blood vessels and dentin-like tissue. Thickening of the root canal wall was also observed [79]. This study demonstrates the feasibility of using stem cell-mediated tissue engineering to realize pulp regeneration in immature teeth.

On the other hand, Zhu et al. transplanted DPSCs and/or PRP into root canals and showed no enhancement in new tissue formation compared with inducement of a blood clot into the root canals alone [80].

Many studies have found clinical success following revascularization procedures, for example, no symptoms and no periapical lesions [81] [82]. However, the histological observations from animal experiments have revealed that the tissues formed in the root canal do not reflect the regeneration of pulp-dentin but are rather formed of periodontal tissues, such as cementum, periodontal ligament, and bone [83]. The revascularization procedure has its own clinical advantages in the treatment of immature teeth, but it does not result in pulp-dentin complex regeneration in the true sense.

Another important aspect worth noting is the role of scaffolds in stem cell regeneration. Conde et al. [84] stated that the relationship between the scaffolds, the environment and the growth factors released from dentine are critical for de novo pulp tissue regeneration.

Misako et al. assessed the efficacy and safety of pulp stem cell transplantation as a prelude before the initiation of clinical trials. Granulocyte-colony stimulat- 
ing factor (G-CSF) induces subsets of dental pulp stem cells to form mobilized dental pulp stem cells (MDPSCs). Therefore, the standardization and establishment of regulatory guidelines for stem cell therapy in clinical endodontics is now a reality [85].

\subsubsection{Human Studies}

Current applications of stem cells in endodontic research have revealed their potential to continue root development in necrotic immature teeth and transplanted/replanted teeth. In a clinical case report Surendran et al. [86] have demonstrated successful application of pulp revascularization and have highlighted the role of dental stem cells as a promising tool for regeneration of individual tissue types like dentine, pulp and even an entire functional tooth.

Shiehzadeh et al. [87] used MSC to treat necrotic/immature teeth with periradicular periodontitis, which was not treated with conventional apexification techniques. All cases developed mature apices and bone healing after 3 to 4 months after the initial treatment without complications, and faster than traditional treatments. Their clinical observations support a shifting paradigm toward a biologic approach by providing a favorable environment for tissue regeneration.

In summary, although vascularized pulp-like tissues have been formed in some experimental and clinical studies, little has been known on the function of the regenerated tissue. Studies on the cell sources of pulp regeneration via cell homing strategy might reveal more information on the signaling molecular selection. The proper signaling molecules for pulp regeneration should facilitate the recruitment of stem cells with the vasculogenic and neurogenic differentiation potential, while inhibiting cells with osteogenic or cementogenic potential (e.g., periodontal ligament cells).

\subsection{Salivary Glands}

Stem cell therapy has been applied to treat radiation induced damage, injury or diseases of the salivary glands. We found a total of 15 animal studies and one human study wherein stem cell therapy was used to treat a patient with Sjogren's syndrome.

\subsubsection{Animal Studies}

\section{Salivary gland regeneration}

Ono $\mathrm{H}$ et al. [88] attempt to regenerate salivary glands using induced pluripotent stem (iPS) cells. Glandular tissues that were similar to the adult submandibular glands (SMGs) and sublingual glands could be partially produced by the transplantation of iPS cells into mouse salivary glands. The coculture of embryonic SMG cells and iPS cells had a better-developed epithelial structure and fewer undifferentiated specific markers than monoculture of embryonic SMG cells. Their results suggest that iPS cells have a potential ability to accelerate differentiation for salivary gland development and regeneration.

Bone marrow cell extract (termed as BM Soup) has been demonstrated to repair irradiated salivary glands (SGs) and restore saliva secretion. Misuno et al. in 
their study showed that BM Soup treatment is effective to restore the function of damaged SGs in NOD mice [89].

\section{Radiation damaged salivary glands}

Various studies have shown that local transplantation of Adipose tissue derived Mesenchymal stem cells (AdMSC) improves tissue-remodeling following radiation damage in SG tissue, and that use of a carrier enhances the protective effects of AdMSC-mediated cellular protection against irradiation induced damage via paracrine secretion and suggest that hAdMSC administration should be viewed as a candidate therapy for the treatment of radiation-induced SG damage [90] [91] [92].

\section{Hyposalivation}

Jeong et al. [93] isolated tissue-specific stem cells from the human submandibular salivary gland (hSGSCs). Transplantation of hSGSCs to radiation-damaged rat salivary glands rescued hyposalivation and body weight loss, restored acinar and duct cell structure, and decreased the amount of apoptotic cells. These data suggests that the isolated hSGSCs, which may have characteristics of mesenchymal-like stem cells, could be used as a cell therapy agent for the damaged salivary gland.

\section{Xerostomia}

Salivary gland hypofunction, also known as xerostomia, occurs as a result of radiation therapy for head cancer, Sjögren's syndrome or aging, and can cause a variety of critical oral health issues, including dental decay, bacterial infection, mastication dysfunction, swallowing dysfunction and reduced quality of life. Ogawa et al. [94] demonstrated the full functional regeneration of a salivary gland that reproduces the morphogenesis induced by reciprocal epithelial and mesenchymal interactions through the orthotopic transplantation of a bioengineered salivary gland germ as a regenerative organ replacement therapy. The bioengineered germ developed into a mature gland through acinar formations with a myoepithelium and innervation. The bioengineered submandibular gland produced saliva in response to the administration of pilocarpine and gustatory stimulation by citrate, protected against oral bacterial infection and restored normal swallowing in a salivary gland-defective mouse model. Their study thus provides a proof-of-concept for bioengineered salivary gland regeneration as a potential treatment of xerostomia.

\subsubsection{Human Studies}

Sjögren syndrome (SS) is a systemic autoimmune disease characterized by dry mouth and eyes, and the cellular and molecular mechanisms for its pathogenesis are complex. Xu et al. for the first time showed that bone marrow mesenchymal stem cells in SS-like NOD/Ltj mice and human patients were defective in immunoregulatory functions. Importantly, treatment with mesenchymal stem cells (MSCs) suppressed autoimmunity and restored salivary gland secretory function in both mouse models and SS patients. They suggested that immunologic regulatory functions of MSCs play an important role in SS pathogenesis, and allogeneic MSC treatment may provide a novel, effective, and safe therapy for pa- 
tients with SS [95].

\section{Hard Tissue Regeneration}

\subsection{Enamel}

Currently a lot of investigators are interested in developing cell-based strategies to regenerate enamel. Like other tissues, regenerative treatments for enamel fundamentally require stem cells, scaffold and growth factors [96].

\section{Cell based strategies}

Huang et al., studied the possibility of using synthetic and bioactive nanostructures that are known to self-assemble in physiologic environments into nanofibers network, in order to mimic the extracellular matrix that surrounds the ameloblasts [97] Ameloblast-like cells and primary enamel organ epithelial (EOE) cells were cultured within Polyacrylamide (PA) hydrogels, and the PA was injected into the enamel organ epithelia of mouse embryonic incisors and transplanted under the kidney capsules in host mice for long-term culture [97].

Further study was done to elucidate the coupling response of integrin receptors to the biomaterial and gene expression profiles. These cues provide an insight into molecular mechanisms involved in enamel formation, which helps in designing synthetic regenerative approaches and to manipulate pathways to control enamel regeneration [98].

\section{Enamel tissue engineering}

Developing a technique to manipulate EOE cells for enamel replacement and attempts are made to generate enamel based on sub-cultured EOE cells using tissue-engineering technology.

Honda et al. examined the enamel-forming capability of sub-cultured EOE cells, by transplanting cells onto a biodegradable scaffold in vivo [99]. Four weeks after transplantation of EOE cells combined with dental pulp cells in scaffolds, several phenomena related to amelogenesis were distinguished in the implants [99]. In the most mature structures, enamel was readily found in the implants. Furthermore, amelogenin immunoreactivity was detected in tall columnar epithelial cells on the surface of the dentin or enamel, indicating that the tissue-engineered enamel contains well-developed ameloblasts. Together, these results indicate that the sub-cultured EOE cells have the potential to generate enamel and provide a promising step towards a new therapy for reforming enamel.

Future trend may be the application of genes for enamel formation.

\subsection{Dentin Regeneration}

Out of a total of 24 animal studies 10 studies demonstrated regeneration of dentin or dentin-like tissue and 14 studies demonstrated the odontogenic potential of stem cells.

\section{Animal studies}

Regeneration of dentin tissues in the pulp space of teeth serves as the ultimate goal of preserving teeth via endodontic approaches. In recent times, many stu- 
dies suggested that human dentin scaffolds combined with dental stem cells was a potential strategy for the complete dentin tissue regeneration. Tran et al. found that DPSCs was able to regenerate dentin-like tissues, which expressed specific dentin markers such as dentin sialophosphoprotein and dentin matrix protein 1 [100].

Reparative dentin formation is essential for maintaining the integrity of dentin structure during disease or trauma. Zheng et al. investigated stem/progenitor cell-based tissue engineering for dentin regeneration in a large animal model. At 16 weeks after transplantation, the PDPSCs mixed with $\beta$-TCP significantly regenerated the dentin-like structures and nearly completely restored the pulp chamber roof defects. This study demonstrated that the PDPSC/scaffold construct was useful in direct pulp-capping and provides pre-clinical evidence for stem/progenitor cell-based dentin regeneration [101].

In a comparative study of human dental follicle cells and human periodontal ligament cells it was observed that although PDLCs could form the dentin-like tissues, the structure of dentin tissues generated by DFCs was more complete [102].

Autologous mesenchymal BMSCs were able to promote hard-tissue formation after direct pulp capping procedures [103].

\subsection{Cementum Regeneration}

A total of 10 animal studies were relevant with regards to cementum regeneration with stem cells. Out of which 5 studies were regarding regeneration of cementum or cementum like tissue [104], 4 studies attempted regeneration of the cementum-PDL complex [105] and 1 study cementum and bone [106].

\section{Animal studies}

These results suggest that the mixed-type hPDLSC pellet could mimic the microenvironment of PDL and enhance the reconstruction of physiologic architecture of a dental cementum/PDL-like complex. This tissue mimicking may also be a promising alternative to promote periodontal defect repair for additional clinical applications [105].

Lee et al. in their study stated that colocalization of biomolecules at zones of the PDL adjacent to attachment sites may be essential for the formation of pre-cementum and osteoid interfaces at a load-bearing bone-PDL-tooth fibrous joint. Biophysical cues resulting from development and function can regulate recruitment and differentiation of stem cells potentially from a vascular origin toward osteo- and cemento-blastic lineages at the PDL-bone and PDL-cementum entheses [107].

The regenerative abilities of cementum with inserted PDL are important for the prevention of tooth loss. Jin et al. investigated the effects of recombinant human plasminogen activator inhibitor-1 (rhPAI-1) on cementogenic differentiation of human PDLSCs (hPDLSCs) and found that rhPAI-1 induced hPDLSCs to regenerate cementum-like tissue with PDL fibers inserted into newly formed cementum-like tissue suggesting that rhPAI-1 may play a key role in cemento- 
genic differentiation of hPDLSCs and may be a good candidate for future clinical applications in periodontal tissue regeneration and possibly in tooth root bioengineering [108].

Local activation of canonical Wnt signaling resulted in in vitro cementogenic differentiation of hPDLCs and significant new cellular cementum deposition and the formation of well-organized periodontal ligament fibers in vivo [109].

\subsection{Bone Regeneration}

Numerous studies have been done in an attempt to regenerate bone. A total of 35 animal studies were successful in regenerating bone and bone like tissues [110] [111]. 5 clinical studies were identified wherein stem cells were used to regenerate functional bone in alveolar deficiencies [112] [113], Mandible defects [114] and craniofacial bone regeneration [115] [116].

\section{Animal studies}

Nakajima et al. collected granulation tissue from dog dental socket 3 days after tooth extraction. The ability of dDSCs to regenerate periodontal tissue in a one-wall defect model resulted in cementum-like and periodontal ligament-like tissues and alveolar bone, whereas only bony tissue was observed in the control group ( $\beta$-TCP/PGA) [117].

Morad et al., reported in vivo use of DPSC for bone regeneration by using different experimental models and types of scaffolds with different results [118]. Cavalcanti et al., and Moshaverinia et al. reported successful bone regeneration using DPSC in alginate or Pura matrix in in vitro and in vivo studies [119] [120].

\section{Peri-Implant bone defect}

During an immediate implant placement the large bone defect peri-implant has a negative influence on the process of bone healing. Various researchers have been able to successfully promote new bone formation and accelerate bone formation in the peri-implant defect with PRF/Umbilical cord mesenchymal stem cells [121], HA-based scaffolds previously seeded with Adipose derived stem cells [122] and BMMSC [123].

\subsection{Clinical Studies}

Using cell therapy, Rajan et al. reported the upper jaw reconstruction of a patient who lost teeth and $75 \%$ of the supporting jawbone following injury. Clinical, radiographic, and histological analyses confirmed that by 4 months, the cell therapy regenerated $80 \%$ of the original jawbone deficiency with vascularized, mineralized bone sufficient to stably place oral implants. Functional and aesthetic rehabilitation of the patient was successfully completed with installation of a dental prosthesis 6 months following implant placement. This proof-of-concept clinical report used an evidence-based approach for the cell transplantation protocol and is the first to describe a cell therapy for craniofacial trauma reconstruction [116].

A clinical trial was performed on seven patients with mandibular bone defects by transplant of DPSC in a collagen scaffold. A 3 years of follow-up, (Giuliani et 
al., 2013) reported good clinical outcomes. The regenerated tissue from the graft sites was composed of a fully compact bone with a higher matrix density than control human alveolar spongy bone from the same patient. Thus, the regenerated bone, being entirely compact, is completely different from normal alveolar bone [114].

In a randomized controlled trial, transplantation of Tissue repair cells (TRCs) from bone marrow for treatment of alveolar bone defects appeared safe and accelerated bone regeneration, enabling jawbone reconstruction [115]. Secreted growth factors and cytokines in the conditioned medium from bone marrow-derived mesenchymal stem cells (MSC-CM) have several effects on cell behavior. Katagiri et al. in their study showed that MSC-CM had great osteogenic potential for regeneration of bone [113]. Injectable tissue-engineered bone (TEB) composed of mesenchymal stem cells (MSCs) and platelet-rich plasma was able to regenerate functional bone in alveolar deficiencies and was able to restore masticatory function in patients [112].

\subsection{Cleft Palate}

Scaffolds are presently employed for cleft palate repair. Scaffolds induce cell growth, host cell migration, cell attachment and absorbs at the rate of bone formation. It allows cell-to-cell interaction and diffusion of nutrients and metabolites [124]. Materials like Collagen [125], Hyaluronic acid [126], Hydroxyapatite [127], Mesoporous bioactive glass [128], Poly (epsilon-caprolactone)/nano-fluoridated hydroxyapatite (PCL-FHA) [129], Platelet rich fibrin (PRF) etc. are used as scaffolds.

4 studies reported success of alveolar defect repair using DPSC [132], BMSC/PRF [130], Adipose derived stem cells [131] and mesenchymal stem cells derived from iliac bone [133].

Both bone marrow-derived mesenchymal stem cells and platelet-rich fibrin are capable of improving the repair of dog alveolar cleft, and the mixture of them is more potent than each one of them used singly for enhancing new bone regeneration [131]. In another study, autografts and tissue-engineered bone were used for bone regeneration. Bone formation on the autograft sides was higher than on the stem cell sides, demonstrating that autograft is still the gold standard for bone regeneration and tissue engineered bone may provide an acceptable alternative [132].

Perfect closure of the jaw cleft in dogs was achieved six months after the transplantation of MSC. The X-ray and histological examination revealed that the regenerated bone on the experimental side was almost equivalent to the original bone adjoining the jaw cleft. It was suggested the application of MSCs with Carbonated Hydroxyapatite (CAP) particles can become a new treatment modality for bone regeneration for cleft lip and palate patients [133].

\section{Human Studies}

Behnia et al. evaluated the effect of recombinant platelet derived growth factor and in vitro osteogenic differentiated human bone marrow mesenchymal stem 
cells (hBMMSCs) in alveolar cleft defects. They reported significant improvement in bone regeneration three months after the operation, suggesting an enhancement effect of recombinant platelet derived growth factor with hMSCs on regeneration capacity of the cells [134].

\section{Whole Tooth Regeneration}

Ikeda et al. reported that Suji $\mathrm{T}$ and team formed a fully functional complete tooth by combining isolated mouse dental epithelial and MSC [135]. In 2011, Oshima et al. reported that the same research group developed a complete tooth unit consisting of a mature tooth, periodontal ligament and alveolar bone, which were transplanted into toothless mouse jaw regions in vivo, and erupted correctly and in occlusion [136]. Angelova Volponi et al. reported success using adult gingival epithelial cells, which upon recombination with mesenchymal cells generate mature teeth and form enamel and dentin [137]. Similarly, Yang et al. generated a complete tooth by implantation of a tooth germ like structure in animal models [138].

In tissue engineering of teeth with stem cells, platelet-rich fibrin (PRF) that is rich in growth factors and cytokines, may improve regeneration. PRF added into fibrin glue to enrich the microenvironment with growth factors shows promising results when transplanted with Dental bud cells. One animal developed a complete tooth with crown, root, pulp, enamel, dentin, odontoblast, cementum, blood vessels, and periodontal ligaments in indiscriminate shape. This study demonstrated that DBCs seeded into fibrin glue-PRF could regenerate a complete tooth [139]. Other authors have employed iPS-derived cells to generate mature bioengineered teeth by similar recombination methods [140] [141].

Although many animal model studies have been reported a complete human study is yet to be documented.

\section{Conclusions}

Stem cell therapy applications are observed to show promising results as future trends points out to successful clinical outcomes.

The present review concludes

1) On comparison between dental hard and soft tissue regeneration and repair via stem cell therapy it has been observed that more number of clinical case reports is seen with dental hard tissue repair than soft tissue.

2) The majority of the studies are still in vivo animal studies in both dental hard and soft tissues.

3) The ultimate aim of stem cell therapy is to regenerate or repair dental tissues without much of surgical hazards.

4) Whole tooth regenerations are still in the animal model research phase.

5) More number of successful clinical follow-ups of more than five years is required to establish credibility of stem cell therapy in oral application.

6) Development of newer scaffolds, understanding cues of various signaling molecules and understanding gene expression and proteomics of stem cells are 
future challenges that will have to be addressed for successful regeneration through stem cell therapy.

\section{References}

[1] Fischbach, G.D. and Fischbach, R.L. (2004) Stem Cells: Science, Policy, and Ethics. The Journal of Clinical Investigation, 114, 1364-1370. https://doi.org/10.1172/JCI200423549

[2] Yamaizumi, M., Mekada, E., Uchida, T. and Okada, Y. (1978) One Molecule of Diphtheria Toxin Fragment an Introduced into a Cell Can Kill the Cell. Cell, 15, 245-250. https://doi.org/10.1016/0092-8674(78)90099-5

[3] Maximow, A. (1990) The Lymphocyte as a Stem Cell, Common to Different Blood Elements in Embryonic Development and during the Post-Fetal Life of Mammals. Folia Haematol, 8,123-134.

[4] Goujon, E. (1869) Recherches experimentales sur les proprietes physiologiques de la moelle des os. Jde L'Anat et de La Physiol, 6, 399-412.

[5] Tavassoli, M. and Crosby, W.H. (1968) Transplantation of Marrow to Extramedullary Sites. Science, 161, 54-56.

https://doi.org/10.1126/science.161.3836.54

[6] Friedenstein, A.J., Deriglasova, U.F., Kulagina, N.N., et al. (1974) Precursors for Fibroblasts in Different Populations of Hematopoietic Cells as Detected by the in $\mathrm{Vi}_{-}$ tro Colony Assay Method. Experimental Hematology, 2, 83-92.

[7] Gronthos, S., Mankani, M., Brahim, J., Robey, P.G. and Shi, S. (2000) Postnatal Human Dental Pulp Stem Cells (DPSCs) in Vitro and in Vivo. Proceedings of the National Academy of Sciences of the USA, 97, 13625-13630. https://doi.org/10.1073/pnas.240309797

[8] Prasad, P., Desai, R., Bansal, S., Shirsat, P. and Raipure, P. (2015) Stem CellsEmerging Concepts in Dentistry. Ann Med Chem Res, 1, 1006.

[9] Egusa, H., et al. (2012) Stem Cells in Dentistry-Part I: Stem Cell Sources. Journal of Prosthodontic Research, 56, 151-165.

[10] Ittenger, M.F., Mackay, A.M., Beck, S.C., Jaiswal, R.K., Douglas, R., Mosca, J.D., Moorman, M.A., Simonetti, D.W., Craig, S. and Marshak, D.R. (1999) Multilineage Potential of Adult Human Mesenchymal Stem Cells. Science, 284, 143-147. https://doi.org/10.1126/science.284.5411.143

[11] Ding, D.C., Shyu, W.C. and Lin, S.Z. (2011) Mesenchymal Stem Cells. Cell Transplant, 20, 5-14. https://doi.org/10.3727/096368910X

[12] Chandra Mouli, P.E., et al. (2012) Stem Cells in Dentistry-A Review. Journal of Pharmaceutical Sciences and Research, 4, 1872-1876.

[13] Matsubara, T., Suardita, K., Ishii, M., Sugiyama, M., Igarashi, A., Oda, R., et al. (2005) Alveolar Bone Marrow as a Cell Source for Regenerative Medicine: Differences between Alveolar and Iliac Bone Marrow Stromal Cells. Journal of Bone and Mineral Research, 20, 399-409. https://doi.org/10.1359/JBMR.041117

[14] Ponnaiyan, D. (2014) Do Dental Stem Cells Depict Distinct Characteristics?-Establishing Their "Phenotypic Fingerprint". Dental Research Journal, 11, 163-172.

[15] Rodriguez-Lozano, F.J. and Moraleda, J.M. (2011) Use of Dental Stem Cells in Regenerative Dentistry: A Possible Alternative. Translational Research, 158, 385-386.

[16] Khanna-Jain, R., Vanhatupa, S., Vuorinen, A., Sandor, G., Suuronen, R., Mannerstrom, B., et al. (2012) Growth and Differentiation of Human Dental Pulp Stem Cells Maintained in Fetal Bovine Serum, Human Serum and Serum-Free/Xeno-Free 
Culture Media. Journal of Stem Cell Research Therapy, 2, 4. https://doi.org/10.4172/2157-7633.1000126

[17] D’Aquino, R., Graziano, A., Sampaolesi, M., Laino, G., Pirozzi, G., De Rosa, A., et al. (2007) Human Postnatal Dental Pulp Cells Co-Differentiate into Osteoblasts and Endotheliocytes: A Pivotal Synergy Leading to Adult Bone Tissue Formation. Cell Death and Differentiation, 14, 162-171. https://doi.org/10.1038/sj.cdd.4402121

[18] Alge, D.L., Zhou, D., Adams, L.L., Wyss, B.K., Shadday, M.D., Woods, E.J., et al. (2010) Donor-Matched Comparison of Dental Pulp Stem Cells and Bone Marrow-Derived Mesenchymal Stem Cells in a Rat Model. Journal of Tissue Engineering and Regenerative Medicine, 4, 73-81.

[19] Hei, W.H., Kim, S., Park, J.C., Seo, Y.K., Kim, S.M., Jahng, J.W. and Lee, J.H. (2016) Schwann-Like Cells Differentiated from Human Dental Pulp Stem Cells Combined with a Pulsed Electromagnetic Field Can Improve Peripheral Nerve Regeneration. Bioelectromagnetics, 37, 163-174.

[20] Syed-Picard, F.N., Du, Y., Lathrop, K.L., Mann, M.M., Funderburgh, M.L. and Funderburgh, J.L. (2015) Dental Pulp Stem Cells: A New Cellular Resource for Corneal Stromal Regeneration. Stem Cells Translational Medicine, 4, 276-285. https://doi.org/10.5966/sctm.2014-0115

[21] Hirose, Y., Yamamoto, T., Nakashima, M., Funahashi, Y., Matsukawa, Y., Yamaguchi, M., Kawabata, S. and Gotoh, M. (2016) Injection of Dental Pulp Stem Cells Promotes Healing of Damaged Bladder Tissue in a Rat Model of Chemically Induced Cystitis. Cell Transplant, 25, 425-436. https://doi.org/10.3727/096368915X689523

[22] Barros, M.A., Martins, J.F., Maria, D.A., Wenceslau, C.V., De Souza, D.M., Kerkis, A., Câmara, N.O., Balieiro, J.C. and Kerkis, I. (2014) Immature Dental Pulp Stem Cells Showed Renotropic and Pericyte-Like Properties in Acute Renal Failure in Rats. Cell Medicine, 7, 95-108. https://doi.org/10.3727/215517914X680038

[23] Li, D., Deng, T., Li, H. and Li, Y. (2015) MiR-143 and MiR-135 Inhibitors Treatment Induces Skeletal Myogenic Differentiation of Human Adult Dental Pulp Stem Cells. Archives of Oral Biology, 60, 1613-1617.

[24] Wakayama, H., Hashimoto, N., Matsushita, Y., Matsubara, K., Yamamoto, N., Hasegawa, Y., Ueda, M. and Yamamoto, A. (2015) Factors Secreted from Dental Pulp Stem Cells Show Multifaceted Benefits for Treating Acute Lung Injury in Mice. $C y$ totherapy, 17, 1119-1129.

[25] Janebodin, K., Zeng, Y., Buranaphatthana, W., Ieronimakis, N. and Reyes, M. (2013) VEGFR2-Dependent Angiogenic Capacity of Pericyte-Like Dental Pulp Stem Cells. Journal of Dental Research, 92, 524-531. https://doi.org/10.1177/0022034513485599

[26] Hynes, K., Menicanin, D., Gronthos, S. and Bartold, P.M. (2012) Clinical Utility of Stem Cells for Periodontal Regeneration. Periodontology 2000, 59, 203-227. https://doi.org/10.1111/j.1600-0757.2012.00443.x

[27] Giordano, G., La Monaca, G., Annibali, S., Cicconetti, A. and Ottolenghi, L. (2011) Stem Cells from Oral Niches: A Review. Annali di Stomatologia, 2, 3-8.

[28] Yamada, Y., Ito, K., Nakamura, S., Ueda, M. and Nagasaka, T. (2011) Promising Cell Based Therapy for Bone Regeneration Using Stem Cells from Deciduous Teeth, Dental Pulp, and Bone Marrow. Cell Transplant, 20, 1003-1013. https://doi.org/10.3727/096368910X539128

[29] Rodríguez-Lozano, F.J., Insausti, C.L., Iniesta, F., Blanquer, M., Ramírez, M.D., et al. (2012) Mesenchymal Dental Stem Cells in Regenerative Dentistry. Medicina Oral, Patologia Oral Y Cirugia Bucal, 17, e1062-e1067. 
https://doi.org/10.4317/medoral.17925

[30] Chandki, R., Kala, M., Banthia, P. and Banthia, R. (2012) From Stem to Roots: Tissue Engineering in Endodontics. Journal of Clinical and Experimental Dentistry, 4, e66-e71. https://doi.org/10.4317/jced.50678

[31] Bansal, R. and Jain, A. (2015) Current Overview on Dental Stem Cells Applications in Regenerative Dentistry. Journal of Natural Science, Biology and Medicine, 6, 29 34. https://doi.org/10.4103/0976-9668.149074

[32] Morsczeck, C., Gotz, W., Schierholz, J., Zeilhofer, F., Kuhn, U., Mohl, C., et al. (2005) Isolation of Precursor Cells (PCs) from Human Dental Follicle of Wisdom Teeth. Matrix Biology, 24, 155-165.

[33] Otabe, K., Muneta, T., Kawashima, N., Suda, H., Tsuji, K. and Sekiya, I. (2012) Comparison of Gingiva, Dental Pulp, and Periodontal Ligament Cells From the Standpoint of Mesenchymal Stem Cell Properties. Cell Medicine, 4, 13-21. https://doi.org/10.3727/215517912X653319

[34] Takahashi, K. and Yamanaka, S. (2006) Induction of Pluripotent Stem Cells from Mouse Embryonic and Adult Fibroblast Cultures by Defined Factors. Cell, 126, 663 676.

[35] Karalashvili, L., Kakabadze, A., Vyshnevska, G. and Kakabadze, Z. (2015) A Cellular Human Amniotic Membrane as a Three-Dimensional Scaffold for the Treatment of Mucogingival Defects. Georgian Medical News, 244-245, 84-89.

[36] Zhang, Q., Nguyen, A.L., Shi, S., Hill, C., Wilder-Smith, P., Krasieva, T.B. and Le, A.D. (2012) Three-Dimensional Spheroid Culture of Human Gingiva-Derived Mesenchymal Stem Cells Enhances Mitigation of Chemotherapy-Induced Oral Mucositis. Stem Cells, 21, 937-947. https://doi.org/10.1089/scd.2011.0252

[37] Kondo, R., Atsuta, I., Ayukawa, Y., Yamaza, T., Matsuura, Y., Furuhashi, A., Tsukiyama, Y. and Koyano, K. (2014) Therapeutic Interaction of Systemically-Administered Mesenchymal Stem Cells with Peri-Implant Mucosa. PLoS ONE, 20, 9.

[38] Tatakis, D.N., Chambrone, L., Allen, E.P., Langer, B., McGuire, M.K., Richardson, C.R., Zabalegui, I. and Zadeh, H.H. (2015) Periodontal Soft Tissue Root Coverage Procedures: A Consensus Report from the AAP Regeneration Workshop. Journal of Periodontology, 86, S52-S55. https://doi.org/10.1902/jop.2015.140376

[39] Zanwar, K., Laxmanrao, B.M., Kumar, G.K., Koudale, B.S. and Gowda, P. (2014) Comparative Evaluation of Efficacy of Stem Cells in Combination with PLA/PGA Membrane versus Sub-Epithelial Connective Tissue for the Treatment of Multiple gingival Recession Defects: A Clinical Study. Journal of Stem Cells, 9, 253-267.

[40] Sharma, A. and Yadav, K. (2015) Amniotic Membrane-A Novel Material for the Root Coverage: A Case Series. Journal of Indian Society of Periodontology, 19, 444448. https://doi.org/10.4103/0972-124x.154166

[41] Yamada, Y., Nakamura, S., Ueda, M. and Ito, K. (2015) Papilla Regeneration by Injectable Stem Cell Therapy with Regenerative Medicine: Long-Term Clinical Prognosis. Journal of Tissue Engineering and Regenerative Medicine, 9, 305-309. https://doi.org/10.1002/term.1737

[42] Hughes, F.J., Ghuman, M. and Talal, A. (2010) Periodontal Regeneration: A Challenge for the Tissue Engineer? Proceedings of the Institution of Mechanical Engineers, Part H, 224, 1345-1358. https://doi.org/10.1243/09544119JEIM820

[43] Wang, H.-L. (2005) Academy Report: Periodontal Regeneration. Journal of Periodontology, 76, 1601-1622. https://doi.org/10.1902/jop.2005.76.9.1601

[44] Venezia, E., Goldstein, M., Boyan, B.D. and Schwartz, Z. (2004) The Use of Enamel Matrix Derivative in the Treatment of Periodontal Defects: A Literature Review and 
Meta-Analysis. Critical Reviews in Oral Biology \& Medicine, 15, 382-402. https://doi.org/10.1177/154411130401500605

[45] Yu, M., Ge, S., Wang, F., Wen, Y., Yan, X., Zeng, Q., Yue, W., Yang, P. and Pei, X. (2013) The Role of Systemically Delivered Bone Marrow-Derived Mesenchymal Stem Cells in the Regeneration of Periodontal Tissues. The International Journal of Oral \& Maxillofacial Implants, 28, e503-e511. https://doi.org/10.11607/jomi.te31

[46] Ji, K., Liu, Y., Lu, W., Yang, F., Yu, J., Wang, X., Ma, Q., Yang, Z., Wen, L. and Xuan, K. (2013) Periodontal Tissue Engineering with Stem Cells from the Periodontal Ligament of Human Retained Deciduous Teeth. Journal of Periodontal Research, 48, 105-116.

[47] Cai, X., Yang, F., Yan, X., Yang, W., Yu, N., Oortgiesen, D.A., Wang, Y., Jansen, J.A. and Walboomers, X.F. (2015) Influence of Bone Marrow-Derived Mesenchymal Stem Cells Pre-Implantation Differentiation Approach on Periodontal Regeneration in Vivo. Journal of Clinical Periodontology, 42, 380-389. https://doi.org/10.1111/jcpe.12379

[48] Yan, X.Z., Yang, F., Jansen, J.A., et al. (2015) Cell-Based Approaches in Periodontal Regeneration: A Systematic Review and Meta-Analysis of Periodontal Defect Models in Animal Experimental Work. Tissue Engineering Part B: Reviews, 21, 411-426. https://doi.org/10.1089/ten.teb.2015.0049

[49] Khorsand, A., Eslaminejad, M.B., Arabsolghar, M., Paknejad, M., Ghaedi, B., Rokn, A.R., Moslemi, N., Nazarian, H. and Jahangir, S. (2013) Autologous Dental Pulp Stem Cells in Regeneration of Defect Created in Canine Periodontal Tissue. The Journal of Oral Implantology, 39, 433-443. https://doi.org/10.1563/AAID-JOI-D-12-00027

[50] Yu, X., Ge, S., Chen, S., Xu, Q., Zhang, J., Guo, H. and Yang, P. (2013) Human Gingiva-Derived Mesenchymal Stromal Cells Contribute to Periodontal Regeneration in Beagle Dogs. Cells Tissues Organs, 198, 428-437. https://doi.org/10.1159/000360276

[51] Sugawara, A. and Sato, S. (2014) Application of Dedifferentiated Fat Cells for Periodontal Tissue Regeneration. Human Cell, 27, 12-21. https://doi.org/10.1007/s13577-013-0075-6

[52] Fu, X., Jin, L., Ma, P., Fan, Z. and Wang, S. (2014) Allogeneic Stem Cells from Deciduous Teeth in Treatment for Periodontitis in Miniature Swine. Journal of Periodontology, 85, 845-851.

[53] Zhang, H., Liu, S., Zhu, B., Xu, Q., Ding, Y. and Jin, Y. (2016) Composite Cell Sheet for Periodontal Regeneration: Crosstalk between Different Types of MSCs in Cell Sheet Facilitates Complex Periodontal-Like Tissue Regeneration. Stem Cell Research \& Therapy, 7, 168.

[54] Wang, Z.-S., et al. (2016) The Use of Platelet-Rich Fibrin Combined with Periodontal Ligament and Jaw Bone Mesenchymal Stem Cell Sheets for Periodontal Tissue Engineering. Scientific Reports, 6, 28126. https://doi.org/10.1038/srep28126

[55] Lekic, P., Rojas, J., Birek, C., Tenenbaum, H. and McCulloch, C.A. (2001) Phenotypic Comparison of Periodontal Ligament Cells in Vivo and in Vitro. Journal of Periodontal Research, 36, 71. https://doi.org/10.1034/j.1600-0765.2001.360202.x

[56] Suaid, F.F., Ribeiro, F.V., Gomes, T.R., Silvério, K.G., Carvalho, M.D., Nociti, F.H., Casati, M.Z. and Sallum, E.A. (2012) Autologous Periodontal Ligament Cells in the Treatment of Class III Furcation Defects: A Study in Dogs. Journal of Clinical Periodontology, 39, 377-384. https://doi.org/10.1111/j.1600-051X.2012.01858.x

[57] Simsek, S.B., Keles, G.C., Baris, S. and Cetinkaya, B.O. (2012) Comparison of Mesenchymal Stem Cells and Autogenous Cortical Bone Graft in the Treatment of 
Class II Furcation Defects in Dogs. Clinical Oral Investigations, 16, 251-258. https://doi.org/10.1007/s00784-010-0486-7

[58] Zhou, L.L., Liu, H.W., Wen, X.X. and Xie, H. (2014) Involvement of Bone Marrow Stem Cells in Periodontal Wound Healing. Chinese Journal of Dental Research, 17, 105-110.

[59] Paknejad, M., Eslaminejad, M.B., Ghaedi, B., Rokn, A.R., Khorsand, A., Etemad-Moghadam, S., et al. (2015) Isolation and Assessment of Mesenchymal Stem Cells Derived from Bone Marrow: Histologic and Histomorphometric Study in a Canine Periodontal Defect. The Journal of Oral Implantology, 41, 284-291. https://doi.org/10.1563/AAID-JOI-D-13-00220

[60] Zang, S., Jin, L., Kang, S., Hu, X., Wang, M., Wang, J., Chen, B., Peng, B. and Wang, Q. (2016) Periodontal Wound Healing by Transplantation of Jaw Bone MarrowDerived Mesenchymal Stem Cells in Chitosan/Anorganic Bovine Bone Carrier into One-Wall Infrabony Defects in Beagles. Journal of Periodontology, 87, 971-981. https://doi.org/10.1902/jop.2016.150504

[61] Menicanin, D., Mrozik, K.M., Wada, N., Marino, V., Shi, S., Bartold, P.M. and Gronthos, S. (2014) Periodontal-Ligament-Derived Stem Cells Exhibit the Capacity for Long-Term Survival, Self-Renewal, and Regeneration of Multiple Tissue Types in Vivo. Stem Cells, 23, 1001-1011. https://doi.org/10.1089/scd.2013.0490

[62] Tsumanuma, Y., Iwata, T., Kinoshita, A., Washio, K., Yoshida, T., Yamada, A., Takagi, R., Yamato, M., Okano, T. and Izumi, Y. (2016) Allogeneic Transplantation of Periodontal Ligament-Derived Multipotent Mesenchymal Stromal Cell Sheets in Canine Critical-Size Supra-Alveolar Periodontal Defect Model. BioResearch Open Access, 5, 22-36. https://doi.org/10.1089/biores.2015.0043

[63] Lemaitre, M., Monsarrat, P., Blasco-Baque, V., Loubières, P., Burcelin, R., Casteilla, L., Planat-Bénard, V. and Kémoun, P. (2016) Periodontal Tissue Regeneration Using Syngeneic Adipose-Derived Stromal Cells in a Mouse Model. Stem Cells Translational Medicine, 6, 656-665.

[64] Han, J., Menicanin, D., Marino, V., Ge, S., Mrozik, K., Gronthos, S. and Bartold, P.M. (2014) Assessment of the Regenerative Potential of Allogeneic Periodontal Ligament Stem Cells in a Rodent Periodontal Defect Model. Journal of Periodontal Research, 49, 333-345. https://doi.org/10.1111/jre.12111

[65] Feng, F., Akiyama, K., Liu, Y., Yamaza, T., Wang, T.M., Chen, J.H., Wang, B.B., Huang, G.T., Wang, S. and Shi, S. (2010) Utility of PDL Progenitors for in Vivo Tissue Regeneration: A Report of 3 Cases. Oral Diseases, 16, 20-28. https://doi.org/10.1111/j.1601-0825.2009.01593.x

[66] Chen, F.M., Gao, L.N., Tian, B.M., Zhang, X.Y., Zhang, Y.J., Dong, G.Y., Lu, H., Chu, Q., Xu, J., Yu, Y., Wu, R.X., Yin, Y., Shi, S. and Jin, Y. (2016) Treatment of Periodontal Intrabony Defects Using Autologous Periodontal Ligament Stem Cells: A Randomized Clinical Trial. Stem Cell Research \& Therapy, 7, 33.

[67] Dhote, R., Charde, P., Bhongade, M. and Rao, J. (2015) Stem Cells Cultured on Beta Tricalcium Phosphate $(\beta$-TCP) in Combination with Recombinant Human Platelet-Derived Growth Factor-BB (rh-PDGF-BB) for the Treatment of Human Infrabony Defects. Journal of Stem Cells, 10, 243-254.

[68] Baba, S., Yamada, Y., Komuro, A., Yotsui, Y., Umeda, M., Shimuzutani, K. and Nakamura, S. (2016) Phase I/II Trial of Autologous Bone Marrow Stem Cell Transplantation with a Three-Dimensional Woven-Fabric Scaffold for Periodontitis. Stem Cells International, 2015, Article ID: 6205910. https://doi.org/10.1155/2016/6205910

[69] Cochran, D.L., Cobb, C.M., Bashutski, J.D., Chun, Y.H., Lin, Z., Mandelaris, G.A., 
McAllister, B.S., Murakami, S. and Rios, H.F. (2015) Emerging Regenerative Approaches for Periodontal Reconstruction: A Consensus Report from the AAP Regeneration Workshop. Journal of Periodontology, 86, S153-S156. https://doi.org/10.1902/jop.2015.140381

[70] Kuang, R., Zhang, Z., Jin, X., Hu, J., Shi, S., Ni, L. and Ma, P.X. (2016) Nanofibrous Spongy Microspheres for the Delivery of Hypoxia-Primed Human Dental Pulp Stem Cells to Regenerate Vascularized Dental Pulp. Acta Biomaterialia, 33, 225-234.

[71] Chen, Y.J., Zhao, Y.H., Zhao, Y.J., Liu, N.X., Lv, X., Li, Q., Chen, F.M. and Zhang, M. (2015) Potential Dental Pulp Revascularization and Odonto-/Osteogenic Capacity of a Novel Transplant Combined with Dental Pulp Stem Cells and Platelet-Rich Fibrin. Cell and Tissue Research, 361, 439-455. https://doi.org/10.1007/s00441-015-2125-8

[72] Dissanayaka, W.L., Hargreaves, K.M., Jin, L., Samaranayake, L.P. and Zhang, C. (2015) The Interplay of Dental Pulp Stem Cells and Endothelial Cells in an Injectable Peptide Hydrogel on Angiogenesis and Pulp Regeneration in Vivo. Tissue Engineering Part A, 21, 550-563. https://doi.org/10.1089/ten.tea.2014.0154

[73] Syed-Picard, F.N., Ray, H.L., Kumta, P.N. and Sfeir, C. (2014) Scaffoldless TissueEngineered Dental Pulp Cell Constructs for Endodontic Therapy. Journal of Dental Research, 93, 250-255. https://doi.org/10.1177/0022034513517901

[74] Choung, H.W., Lee, J.H., Lee, D.S., Choung, P.H. and Park, J.C. (2013) The Role of Preameloblast-Conditioned Medium in Dental Pulp Regeneration. Journal of Molecular Histology, 44, 715-721. https://doi.org/10.1007/s10735-013-9513-8

[75] Jia, W., Zhao, Y., Yang, J., Wang, W., Wang, X., Ling, L. and Ge, L. (2016) Simvastatin Promotes Dental Pulp Stem Cell-Induced Coronal Pulp Regeneration in Pulpotomized Teeth. Journal of Endodontics, 42, 1049-1054.

[76] Tsutsui, T.W. (2015) In Vivo Stem Cell transplantation Using Reduced Cell Numbers. Methods in Molecular Biology, 1212, 201-207. https://doi.org/10.1007/7651_2014_120

[77] Ito, T., Kaneko, T., Sueyama, Y., Kaneko, R. and Okiji, T. (2016) Dental Pulp Tissue Engineering of Pulpotomized Rat Molars with Bone Marrow Mesenchymal Stem Cells. Odontology, 1-6. https://doi.org/10.1007/s10266-016-0283-0

[78] Ishizaka, R., Hayashi, Y., Iohara, K., Sugiyama, M., Murakami, M., Yamamoto, T., Fukuta, O. and Nakashima, M. (2013) Stimulation of Angiogenesis, Neurogenesis and Regeneration by Side Population Cells from Dental Pulp. Biomaterials, 34, 1888-1897.

[79] Wang, Y., Zhao, Y., Jia, W., Yang, J. and Ge, L. (2013) Preliminary Study on Dental Pulp Stem Cell-Mediated Pulp Regeneration in Canine Immature Permanent Teeth. Journal of Endodontics, 39, 195-201.

[80] Zhu, X., Zhang, C., Huang, G.T., Cheung, G.S., Dissanayaka, W.L. and Zhu, W. (2012) Transplantation of Dental Pulp Stem Cells and Platelet-Rich Plasma for Pulp Regeneration. Journal of Endodontics, 38, 1604-1609.

[81] Jung, I.-Y. and Lee, S.-J. (2008) Hargreaves K. M. Biologically Based Treatment of Immature Permanent Teeth with Pulpal Necrosis: A Case Series. Journal of Endodontics, 34, 876-887.

[82] Ding, R.Y., Cheung, G.S.-P., Chen, J., Yin, X.Z., Wang, Q.Q. and Zhang, C.F. (2016) Pulp Revascularization of Immature teeth with Apical Periodontitis: A Clinical Study. Journal of Endodontics, 35, 745-749.

[83] Torabinejad, M., Faras, H., Corr, R., Wright, K.R. and Shabahang, S. (2014) Histologic Examinations of Teeth Treated with 2 Scaffolds: A Pilot Animal Investigation. 
Journal of Endodontics, 40, 515-520.

[84] Conde, M.C., Chisini, L.A., Demarco, F.F., Nör, J.E., Casagrande, L. and Tarquinio, S.B. (2016) Stem Cell-Based Pulp Tissue Engineering: Variables Enrolled in Translation from the Bench to the Bedside, a Systematic Review of Literature. International Endodontic Journal, 49, 543-550. https://doi.org/10.1111/iej.12489

[85] Nakashima, M. and Iohara, K. (2014) Mobilized Dental Pulp Stem Cells for Pulp Regeneration: Initiation of Clinical Trial. Journal of Endodontics, 40, S26-S32.

[86] Surendran, S. and Sivamurthy, G. (2015) Current Applications and Future Prospects of Stem Cells in Dentistry. Dental Update, 42, 556-558, 560-561.

[87] Shiehzadeh, V., Aghmasheh, F., Shiehzadeh, F., Joulae, M., Kosarieh, E. and Shiehzadeh, F. (2014) Healing of Large Periapical Lesions Following Delivery of Dental Stem Cells with an Injectable Scaffold: New Method and Three Case Reports. Indian Journal of Dental Research, 25, 248-253. https://doi.org/10.4103/0970-9290.135937

[88] Ono, H., Obana, A., Usami, Y., Sakai, M., Nohara, K., Egusa, H. and Sakai, T. (2015) Regenerating Salivary Glands in the Microenvironment of Induced Pluripotent Stem Cells. BioMed Research International, 2015, Article ID: 293570. https://doi.org/10.1155/2015/293570

[89] Misuno, K., Tran, S.D., Khalili, S., Huang, J., Liu, Y. and Hu, S. (2014) Quantitative Analysis of Protein and Gene Expression in Salivary Glands of Sjogren's-Like Disease NOD Mice Treated by Bone Marrow Soup. PLoS ONE, 9, e87158. https://doi.org/10.1371/journal.pone.0087158

[90] Choi, J.S., An, H.Y., Shin, H.S., Kim, Y.M. and Lim, J.Y. (2016) Enhanced Tissue Remodeling Efficacy of Adipose-Derived Mesenchymal Stem Cells Using Injectable Matrices in Radiation Damaged Salivary Gland Model. Journal of Tissue Engineering and Regenerative Medicine. https://doi.org/10.1002/term.2352

[91] Lim, J.Y., Ra, J.C., Shin, I.S., Jang, Y.H., An, H.Y., Choi, J.S., Kim, W.C. and Kim, Y.M. (2013) Systemic Transplantation of Human Adipose Tissue-Derived Mesenchymal Stem Cells for the Regeneration of Irradiation-Induced Salivary Gland Damage. PLoS ONE, 8, e71167.

[92] Xiong, X., Shi, X. and Chen, F. (2014) Human Adipose Tissue-Derived Stem Cells Alleviate Radiation-Induced Xerostomia. International Journal of Molecular Medicine, 34, 749-755. https://doi.org/10.3892/ijmm.2014.1837

[93] Jeong, J., Baek, H., Kim, Y.J., Choi, Y., Lee, H., Lee, E., Kim, E.S., Hah, J.H., Kwon, T.K., Choi, I.J. and Kwon, H. (2013) Human Salivary Gland Stem Cells Ameliorate Hyposalivation of Radiation-Damaged Rat Salivary Glands. Experimental \& Molecular Medicine, 45, e58. https://doi.org/10.1038/emm.2013.121

[94] Ogawa, M., Oshima, M., Imamura, A., Sekine, Y., Ishida, K., Yamashita, K., Nakajima, K., Hirayama, M., Tachikawa, T. and Tsuji, T. (2013) Functional Salivary Gland Regeneration by Transplantation of a Bioengineered Organ Germ. Nature Communications, 4, 2498. https://doi.org/10.1038/ncomms3498

[95] Xu, J., Wang, D., Liu, D., Fan, Z., Zhang, H., Liu, O., Ding, G., Gao, R., Zhang, C., Ding, Y., Bromberg, J.S., Chen, W., Sun, L. and Wang, S. (2012) Allogeneic Mesenchymal Stem Cell Treatment Alleviates Experimental and Clinical Sjögren Syndrome. Blood, 120, 3142-3151. https://doi.org/10.1182/blood-2011-11-391144

[96] Jayasudha, H.K.N. and Baswaraj, K.B.P. (2014) Enamel Regeneration-Current Progress and Challenges. Journal of Clinical and Diagnostic Research, 8, ZE06ZE09.

[97] Huang, Z., Sargeant, T.D., Hulvat, J.F., Mata, A., Bringas, P.J. and Ko, C.-Y. (2008) Bioactive Nanofibers Instruct Cells to Proliferate and Differentiate during Enamel Regeneration. Journal of Bone and Mineral Research, 23, 1995-2006. 
https://doi.org/10.1359/jbmr.080705

[98] Huang, Z., Newcomb, C.J., Zhou, Y., Lei, Y.P., Bringas, P., Stupp, S.I., et al. (2013) The Role of Bioactive Nanofibers in Enamel Regeneration Mediated through Integrin Signals Acting upon C/EBP $\beta$ and c-Jun. Biomaterials, 34, 3303-3314.

[99] Honda, M.J. and Hata, K.-I. (2010) Enamel Tissue Engineering. In: Eberli, D., Ed., Tissue Engineering, INTECH, Rijeka.

[100] Tran Hle, B. and Doan, V.N. (2015) Human Dental Pulp Stem Cells Cultured onto Dentin Derived Scaffold Can Regenerate Dentin-Like Tissue in Vivo. Cell Tissue Bank, 16, 559-568. https://doi.org/10.1007/s10561-015-9503-Z

[101] Zheng, Y., Wang, X.Y., Wang, Y.M., Liu, X.Y., Zhang, C.M., Hou, B.X. and Wang, S.L. (2012) Dentin Regeneration Using Deciduous Pulp Stem/Progenitor Cells. Journal of Dental Research, 91, 676-682. https://doi.org/10.1177/0022034512449834

[102] Tian, Y., Bai, D., Guo, W., Li, J., Zeng, J., Yang, L., Jiang, Z., Feng, L., Yu, M. and Tian, W. (2015) Comparison of Human Dental Follicle Cells and Human Periodontal Ligament Cells for Dentin Tissue Regeneration. Regenerative Medicine, 10, 461-479. https://doi.org/10.2217/rme.15.21

[103] Obeid, M., Saber Sel, D., Ismael Ael, D. and Hassanien, E. (2013) Mesenchymal Stem Cells Promote Hard-Tissue Repair after Direct Pulp Capping. Journal of Endodontics, 39, 626-631.

[104] Choi, H., Jin, H., Kim, J.Y., Lim, K.T., Choung, H.W., Park, J.Y., Chung, J.H. and Choung, P.H. (2014) Hypoxia Promotes CEMP1 Expression and Induces Cementoblastic Differentiation of Human Dental Stem Cells in an HIF-1-Dependent Manner. Tissue Engineering Part A, 20, 410-423. https://doi.org/10.1089/ten.tea.2013.0132

[105] Xie, H. and Liu, H. (2012) A Novel Mixed-Type Stem Cell Pellet for Cementum/Periodontal Ligament-Like Complex. Journal of Periodontology, 83, 805-815. https://doi.org/10.1902/jop.2011.110267

[106] Treves-Manusevitz, S., Hoz, L., Rachima, H., Montoya, G., Tzur, E., Vardimon, A., Narayanan, A.S., Amar, S., Arzate, H. and Pitaru, S. (2013) Stem Cells of the Lamina Propria of Human Oral Mucosa and Gingiva Develop into Mineralized Tissues in Vivo. Journal of Clinical Periodontology, 40, 73-81. https://doi.org/10.1111/jcpe.12016

[107] Lee, J.H., Pryce, B.A., Schweitzer, R., Ryder, M.I. and Ho, S.P. (2015) Differentiating Zones at Periodontal Ligament-Bone and Periodontal Ligament-Cementum Entheses. Journal of Periodontal Research, 50, 870-880. https://doi.org/10.1111/jre.12281

[108] Jin, H., Choung, H.W., Lim, K.T., Jin, B., Jin, C., Chung, J.H. and Choung, P.H. (2015) Recombinant Human Plasminogen Activator Inhibitor-1 Promotes Cementogenic Differentiation of Human Periodontal Ligament Stem Cells. Tissue Engineering Part A, 21, 2817-2828. https://doi.org/10.1089/ten.tea.2014.0399

[109] Han, P., Ivanovski, S., Crawford, R. and Xiao, Y. (2015) Activation of the Canonical Wnt Signaling Pathway Induces Cementum Regeneration. Journal of Bone and Mineral Research, 30, 1160-1174. https://doi.org/10.1002/jbmr.2445

[110] Chamieh, F., Collignon, A.M., Coyac, B.R., Lesieur, J., Ribes, S., Sadoine, J., Llorens, A., Nicoletti, A., Letourneur, D., Colombier, M.L., Nazhat, S.N., Bouchard, P., Chaussain, C. and Rochefort, G.Y. (2016) Accelerated Craniofacial Bone Regeneration through Dense Collagen Gel Scaffolds Seeded with Dental Pulp Stem Cells. Scientific Reports, 6, 38814. https://doi.org/10.1038/srep38814

[111] Al-Hezaimi, K., Ramalingam, S., Al-Askar, M., ArRejaie, A.S., Nooh, N., Jawad, F. Aldahmash, A., Atteya, M. and Wang, C.Y. (2016) Real-Time-Guided Bone Rege- 
neration around Standardized Critical Size Calvarial Defects Using Bone Marrow-Derived Mesenchymal Stem Cells and Collagen Membrane with and without Using Tricalcium Phosphate: An in Vivo Micro-Computed Tomographic and Histologic Experiment in Rats. International Journal of Oral Science, 8, 7-15. https://doi.org/10.1038/ijos.2015.34

[112] Yamada, Y., Nakamura, S., Ito, K., Umemura, E., Hara, K., Nagasaka, T., Abe, A., Baba, S., Furuichi, Y., Izumi, Y., Klein, O.D. and Wakabayashi, T. (2013) Injectable Bone Tissue Engineering Using Expanded Mesenchymal Stem Cells. Stem Cells, 31, 572-580. https://doi.org/10.1002/stem.1300

[113] Katagiri, W., Osugi, M., Kawai, T. and Hibi, H. (2016) First-in-Human Study and Clinical Case Reports of the Alveolar Bone Regeneration with the Secretome from Human Mesenchymal Stem Cells. Head \& Face Medicine, 12, 5.

[114] Giuliani, A., Manescu, A., Langer, M., Rustichelli, F., Desiderio, V., Paino, F., et al. (2013) Three Years after Transplants in Human Mandibles, Histological and InLine Holotomography Revealed That Stem Cells Regenerated a Compact Rather Than a Spongy Bone: Biological and Clinical Implications. Stem Cells Translational Medicine, 2, 316-324. https://doi.org/10.5966/sctm.2012-0136

[115] Kaigler, D., Pagni, G., Park, C.H., Braun, T.M., Holman, L.A., Yi, E., Tarle, S.A., Bartel, R.L. and Giannobile, W.V. (2013) Stem Cell Therapy for Craniofacial Bone Regeneration: A Randomized, Controlled Feasibility Trial. Cell Transplant, 22, 767 777. https://doi.org/10.3727/096368912X652968

[116] Rajan, A., Eubanks, E., Edwards, S., Aronovich, S., Travan, S., Rudek, I., Wang, F., Lanis, A. and Kaigler, D. (2014) Optimized Cell Survival and Seeding Efficiency for Craniofacial Tissue Engineering Using Clinical Stem Cell Therapy. Stem Cells Translational Medicine, 3, 1495-1503. https://doi.org/10.5966/sctm.2014-0039

[117] Nakajima, R., et al. (2014) Mesenchymal Stem/Progenitor Cell Isolation from Tooth Extraction Sockets. Journal of Dental Research, 93, 1133-1140. https://doi.org/10.1177/0022034514549377

[118] Morad, G., Kheiri, L. and Khojasteh, A. (2013) Dental Pulp Stem Cells for in Vivo Bone Regeneration: A Systematic Review of Literature. Archives of Oral Biology, 58, 1818-1827.

[119] Cavalcanti, B.N., Zeitlin, B.D. and Nör, J.E. (2013) A Hydrogel Scaffold That Maintains Viability and Supports Differentiation of Dental Pulp Stem Cells. Dental Materials, 29, 97-102.

[120] Moshaverinia, A., Chen, C., Akiyama, K., Xu, X., Chee, W.W., Schricker, S.R., et al. (2013) Encapsulated Dental-Derived Mesenchymal Stem Cells in an Injectable and Biodegradable Scaffold for Applications in Bone Tissue Engineering. Journal of Biomedical Materials Research Part A, 101, 3285-3294. https://doi.org/10.1002/jbm.a.34546

[121] Hao, P.J., Wang, Z.G., Xu, Q.C., Xu, S., Li, Z.R., Yang, P.S. and Liu, Z.H. (2014) Effect of Umbilical Cord Mesenchymal Stem Cell in Peri-Implant Bone Defect after Immediate Implant: An Experiment Study in Beagle Dogs. International Journal of Clinical and Experimental Medicine, 7, 4131-4138.

[122] Bressan, E., Botticelli, D., Sivolella, S., Bengazi, F., Guazzo, R., Sbricoli, L., Ricci, S., Ferroni, L., Gardin, C., Velez, J.U. and Zavan, B. (2015) Adipose-Derived Stem Cells as a Tool for Dental Implant Osseointegration: An Experimental Study in the Dog. International Journal of Molecular and Cellular Medicine, 4, 197-208.

[123] Zheng, R.C., Park, Y.K., Cho, J.J., Kim, S.K., Heo, S.J., Koak, J.Y. and Lee, J.H. (2014) Bone Regeneration at Dental Implant Sites with Suspended Stem Cells. Journal of Dental Research, 93, 1005-1013. 
https://doi.org/10.1177/0022034514548706

[124] Sharma, B. and Elisseeff, J.H. (2004) Engineering Structurally Organized Cartilage and Bone Tissues. Annals of Biomedical Engineering, 32, 148-159. https://doi.org/10.1023/b:abme.0000007799.60142.78

[125] Krishnamoorthy, G., Sehgal, P.K., Mandal, A.B. and Sadulla, S. (2013) Novel Collagen Scaffolds Prepared by Using Unnatural D-Amino Acids Assisted EDC/NHS Cross Linking. Journal of Biomaterials Science, Polymer Edition, 24, 344-364. https://doi.org/10.1080/09205063.2012.690280

[126] Kang, S.W., Kim, J.S., Park, K.S., Cha, B.H., Shim, J.H., Kim, J.Y., et al. (2011) Surface Modification with Fibrin/Hyaluronic Acid Hydrogel on Solid-Free Form-Based Scaffolds Followed by BMP-2 Loading to Enhance Bone Regeneration. Bone, 48, 298-306.

[127] Sellgren, K.L. and Ma, T. (2012) Perfusion Conditioning of Hydroxyapatite-Chitosan-Gelatin Scaffolds for Bone Tissue Regeneration from Human Mesenchymal Stem Cells. Journal of Tissue Engineering and Regenerative Medicine, 6, 49-59. https://doi.org/10.1002/term.396

[128] Wu, C., Zhou, Y., Fan, W., Han, P., Chang, J., Yuen, J., et al. (2012) Hypoxia-Mimicking Mesoporous Bioactive Glass Scaffolds with Controllable Cobalt Ion Release for Bone Tissue Engineering. Biomaterials, 33, 2076-2085.

[129] Johari, N., Fathi, M.H., Golozar, M.A., Erfani, E. and Samadikuchaksaraei, A. (2012) Poly(epsilon-caprolactone)/nano Fluoridated Hydroxyapatite Scaffolds for Bone Tissue Engineering: In Vitro Degradation and Biocompatibility Study. Journal of Materials Science: Materials in Medicine, 23, 763-770. https://doi.org/10.1007/s10856-011-4528-8

[130] Jahanbin, A., Rashed, R., Alamdari, D.H., Koohestanian, N., Ezzati, A., Kazemian, M., Saghafi, S. and Raisolsadat, M.A. (2016) Success of Maxillary Alveolar Defect Repair in Rats Using Osteoblast-Differentiated Human Deciduous Dental Pulp Stem Cells. Journal of Oral and Maxillofacial Surgery, 74, 829.e1-9.

[131] Yuanzheng, C., Yan, G., Ting, L., Yanjie, F., Peng, W. and Nan, B. (2015) Enhancement of the Repair of Dog Alveolar Cleft by an Autologous Iliac Bone, Bone Marrow-Derived Mesenchymal Stem Cell, and Platelet-Rich Fibrin Mixture. Plastic and Reconstructive Surgery, 135, 1405-1412. https://doi.org/10.1097/PRS.0000000000001166

[132] Pourebrahim, N., Hashemibeni, B., Shahnaseri, S., Torabinia, N., Mousavi, B., Adibi, S., Heidari, F. and Alavi, M.J. (2013) A Comparison of Tissue-Engineered Bone from Adipose-Derived Stem Cell with Autogenous Bone Repair in Maxillary Alveolar Cleft Model in Dogs. International Journal of Oral and Maxillofacial Surgery, 42, 562-568.

[133] Yoshioka, M., Tanimoto, K., Tanne, Y., Sumi, K., Awada, T., Oki, N., Sugiyama, M., Kato, Y. and Tanne, K. (2012) Bone Regeneration in Artificial Jaw Cleft by Use of Carbonated Hydroxyapatite Particles and Mesenchymal Stem Cells Derived from Iliac Bone. International Journal of Dentistry, 2012, Article ID: 352510. https://doi.org/10.1155/2012/352510

[134] Behnia, H., Khojasteh, A., Soleimani, M., Tehranchi, A. and Atashi, A. (2012) Repair of Alveolar Cleft Defect with Mesenchymal Stem Cells and Platelet Derived Growth Factors: A Preliminary Report. Journal of Cranio-Maxillofacial Surgery, 40, 2-7.

[135] Ikeda, R., Morita, K., Nakao, K., Ishida, K., Nakamura, T., Takano-Yamamoto, T., et al. (2009) Fully Functional Bioengineered Tooth Replacement as an Organ Replacement Therapy. Proceedings of the National Academy of Sciences, 106, 13475 
13480. https://doi.org/10.1073/pnas.0902944106

[136] Oshima, M., Mizuno, M., Imamura, A., Ogawa, M., Yasukawa, M., Yamazaki, H., et al. (2011) Functional Tooth Regeneration Using a Bioengineered Tooth Unit as a Mature Organ Replacement Regenerative Therapy. PLoS ONE, 6, e21531. https://doi.org/10.1371/journal.pone.0021531

[137] Angelova, V.A., Kawasaki, M. and Sharpe, P.T. (2013) Adult Human Gingival Epithelial Cells as a Source for Whole-Tooth Bioengineering. Journal of Dental Research, 92, 329-334. https://doi.org/10.1177/0022034513481041

[138] Yang, K.C., Kitamura, Y., Wu, C.C., Chang, H.H., Ling, T.Y. and Kuo, T.F. (2016) Tooth Germ-Like Construct Transplantation for Whole-Tooth Regeneration: An in Vivo Study in the Miniature Pig. Artificial Organs, 40, E39-E50. https://doi.org/10.1111/aor.12630

[139] Yang, K.C., Wang, C.H., Chang, H.H., Chan, W.P., Chi, C.H. and Kuo, T.F. (2012) Fibrin Glue Mixed with Platelet-Rich Fibrin as a Scaffold Seeded with Dental Bud Cells for Tooth Regeneration. Journal of Tissue Engineering and Regenerative Medicine, 6, 777-785. https://doi.org/10.1002/term.483

[140] Wen, Y., Wang, F., Zhang, W., Li, Y., Yu, M., Nan, X., et al. (2012) Application of Induced Pluripotent Stem Cells in Generation of a Tissue-Engineered Tooth-Like Structure. Tissue Engineering Part A, 18, 1677-1685. https://doi.org/10.1089/ten.tea.2011.0220

[141] Cai, J., Zhang, Y., Liu, P., Chen, S., Wu, X., Sun, Y., et al. (2013) Generation of Tooth-Like Structures from Integration-Free Human Urine Induced Pluripotent Stem Cells. Cell Regeneration, 2, 6. https://doi.org/10.1186/2045-9769-2-6

Submit or recommend next manuscript to SCIRP and we will provide best service for you:

Accepting pre-submission inquiries through Email, Facebook, LinkedIn, Twitter, etc. A wide selection of journals (inclusive of 9 subjects, more than 200 journals) Providing 24-hour high-quality service User-friendly online submission system Fair and swift peer-review system Efficient typesetting and proofreading procedure Display of the result of downloads and visits, as well as the number of cited articles Maximum dissemination of your research work

Submit your manuscript at: http://papersubmission.scirp.org/ Or contact ojst@scirp.org 